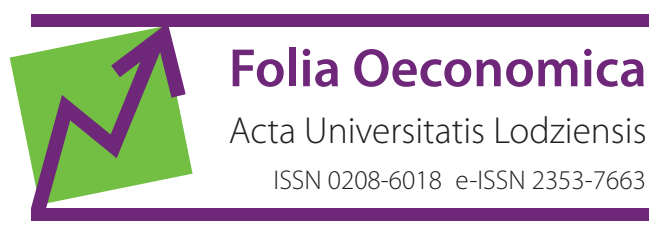

www.czasopisma.uni.lodz.pl/foe/

$1(333) 2018$

DOI: http://dx.doi.org/10.18778/0208-6018.333.04

\title{
Konrad Żelazowski
}

University of Łódź, Faculty of Economics and Sociology, Department of Investment and Real Estate, kzelazowski@uni.lodz.pl

\section{Synchronisation of Price Cycles in European Housing Markets}

\begin{abstract}
The housing market plays a crucial role in every economy. Its importance is determined not only by the size of the housing sector but also by the number of socio-economic functions of residential properties. Just as any other market or economy in general, the housing sector develops cyclically. Housing cycles were traditionally considered to be driven by domestic factors. However economic integration among the countries of the European Union has fostered a general tendency towards synchronisation of national housing cycles. The aim of the research was to identify the properties of housing cycles in selected European countries as well as to verify the degree of their synchronisation. The study covered residential markets in Belgium, France, Holland, Germany, Great Britain, and Italy in the years 1971-2014. The Christiano-Fitzgerald filter was used to isolate price cycles, while correlation coefficients and the concordance index were used to assess synchronisation. The obtained results confirmed the occurrence of the phenomenon of synchronisation of housing cycles. Its intensity increased at the end of the 1990s, and one of the main causes for this increase was the introduction of a single European currency and the accompanying convergence of financial markets.
\end{abstract}

Keywords: European housing markets, housing cycles, synchronisation of housing cycles

JEL: R31, E32 


\section{Introduction}

The housing market is not only an important component of the national economy; it is also a fundamental element, necessary for a good functioning of households. The total expenditure on the housing sector in developed economies is estimated at $10-25 \%$ of GDP (Nykiel, 2008: 51). In addition, residential properties are a major component of households' assets (their share in the total assets of households varies between $40-80 \%$ ). The housing market is also strongly linked to complementary markets, including the construction market, the labour market and the financial market. Fluctuations in the activity of the housing market and cyclical changes in residential property prices have therefore real micro and macro consequences.

Housing cycles are primarily of local and national character. This results mainly from the specificity of real estate (primarily from its immobility), historical factors (which determine the ownership structure of the market and the level of satisfaction of the housing needs of citizens), economic conditions (defining the purchasing power of households in the housing market, the profitability of housing investment, the availability of resources and the cost of housing financing), as well as institutional conditions (defining the legal framework for the functioning of the market, the form and scope of public intervention, and market transparency). However, the processes of removal of barriers to trade, free movement of capital, the dynamic development of the financial sector, as well as the assimilation of patterns of consumption and investment processes observed under globalisation (Micał, 2008), are the source of the housing cycle synchronisation phenomenon.

The purpose of this paper is to identify and characterise the cycles in housing markets in selected European economies and to assess the level of their synchronisation. The study covered the years 1971-2014. The Christiano-Fitzgerald band pass filter was used to identify the cyclical component of a time series, while the evaluation of interdependence and the degree of synchronisation of cycles was carried out with the use of correlation coefficients and concordance indices.

\section{Housing markets cycles and determinants of their synchronisation}

The housing market, similarly to other markets and the economy in general, is developing at a variable rate. Fluctuations of its activity, determined largely by economic conditions, create housing cycles. In traditional terms, the housing cycle is defined as "activity fluctuations of the market, measured by changes in residential property prices, the number of concluded transactions or the number of implemented residential projects expressed in absolute terms through the levels of the 
variable" (Lis, 2015: 38). According to the modern interpretation, the housing cycle is characterised as "fluctuations in supply, demand, prices of real estate and resources around their long-term trends" (Kucharska-Stasiak, 2016: 100).

The analysis of cyclical changes in the housing sector is a complex process. This is due to a lack of a universal indicator of the market situation. Residential property price indices, indices of rental rates, the number of purchase and sale transactions carried out in the market, or the number of implemented and completed residential projects are among the variables most commonly taken into account as a barometer of economic situation in the housing market in empirical research. Consequently, it is difficult to talk about one housing cycle, more often the existence of a set of cycles is indicated. It includes, among others, price and quantity cycles (identified based on the type of a variable taken into account as a barometer of economic situation in the housing market), or demand and supply cycles (identified on the basis of the processes which generate them).

The mechanism of formation of housing cycles and their course is also complex. This market, as any other, is influenced by market conditions. In this context, the main factors that induce fluctuations in the housing market are changes in household incomes, changes in interest rates and mortgage loans availability, as well as changes in the cost of housing construction (ECB, 2003: 23). Demographic factors, including, among others, migrations or changes in the number and structure of households may also have a pro-cyclical impact on the housing market. Due to its socially significant functions, this market is furthermore subject to regulations and public intervention to a greater extent than it is the case with other markets. Changes within housing policies (especially if they are focused only on the demand side or supply side of the market) can be another source of cyclical changes in the housing market. An overview of the main theories and models explaining the mechanisms of cyclic development of the housing sector is included, among others, in the works of R. Barras (1994), D. DiPasquale, W. Wheaton (1994) and P. Lis (2015).

The special nature of the housing market (which is both a consumer and an investment market), and a wide spectrum of factors affecting its operation, mean that housing cycles "are not a simple representation of global economic cycles, and can be more violent and longer or forced and shorter. These differences are due to the forces within the real estate sector" (Kucharska-Stasiak, 2008: 42).

Over the past 25 years significant changes in the course of housing cycles have been observed. Under the influence of liberalisation of capital flows and the growing scale of global direct as well as portfolio investments, national housing cycles have become increasingly synchronised. Some researchers even put forward the hypothesis of the presence of a global real estate cycle (Kucharska-Stasiak, 2016: 113). Among the key factors initiating and enhancing the process of synchronisation of housing markets in international terms, the literature frequently mentions: 
1. Globalisation. Phenomena accompanying the formation of the global market, such as faster spread of information and technology, liberalisation and deregulation of financial markets, increased trade, and an increased scale of international investment have a fundamental impact on the development path of housing markets (Sporek, 2015: 50). Under the conditions of the global economy, also the transactions implemented in the real estate market become global. The former local and national housing market takes on the character of an international market (Kucharska-Stasiak, 2016).

2. The process of financialisation of the housing market. Since the 1980 s, a gradual increase has been taking place in the role of the financial sector in the development of real estate market activity. This process takes various forms ranging from rising household debt driven by mortgage loans to rapid development and popularisation of financial instruments related to real estate. The expansion of real estate financial products such as investment certificates of real estate funds, mortgage backed-securities (MBS), and derivatives associated with the real estate market increase the availability and inflow of investment capital to housing markets. As a result of these changes, fluctuations in investment activity of markets and real estate prices exhibit increasing similarity (Gołębiowski, Szczepankowski, 2015: 200; Cagnina, 2009: 152).

3. The spill-over effects of investment activity in real estate markets. The growing global free movement of capital investment entails the spread of processes taking place in the leading markets to other areas. The so-called import of investor sentiment is a special case of this phenomenon. It is associated with duplication of investment directions and investment decisions in the international dimension. These processes result in synchronisation of the growth and decline phases in investment markets (Frączek, Mazurkiewicz, 2013: 120).

4. The growing importance of residential real estate as an investment asset. One of the important features of the residential real estate is its dual character. By ensuring housing services it is a consumer good, fundamental to every household, but it is also an investment good. Institutional and individual investors seeking alternative forms of capital allocation increasingly direct their attention also to housing markets. These trends have been confirmed by the experiences of the recent global economic crisis, as speculative housing investments were one of the main reasons of the crisis.

The identification of factors that deepen convergence processes and synchronisation of European residential markets is not, however, unequivocal. Pomogajko and Voigtlander indicate primarily the convergence of business cycles and a common monetary policy as the sources of synchronisation of housing cycles (Pomogajko, Voigtlander, 2012). Studies by Igan et al. emphasise the role of financial globalisation and synchronisation of financial markets in synchronisation of housing price cycles (Igan et al., 2010). Vansteenkiste and Hiebert also confirm the occur- 
rence of moderate price spillover effect of house price shocks in European markets (Vansteenkiste, Hiebert, 2009). In addition, harmonisation of tax or social policies within the EU reinforces the tendency to form a common European housing cycle (Alvarez et al., 2010).

\section{The course and synchronisation of price cycles in European housing markets}

\subsection{Data and methodology}

An analysis of the scale of synchronisation of housing cycles was carried out for six European economies: Belgium, France, Holland, Germany, Great Britain and Italy. These countries were among the first active participants in the history of European integration (within the framework of the European Coal and Steel Community, the European Economic Community, and the European Union in its present form). In addition, the countries under study, except Great Britain, have belonged to the euro zone since 1999, when it was established. The common currency and monetary policy are, according to the literature on the subject, one of the fundamental factors fostering the convergence of housing markets.

The price indices for residential property in national markets, obtained from the OECD database, were used as a barometer for the economic situation of the housing market and the basis for identifying cycles (price indices were taken into account in the logarithmised form). The study covered a period of 44 years (1971-2014) with regard to quarterly data (see Table 1)

Table 1. Sources of data used in the study

\begin{tabular}{|l|l|l|l|}
\hline \multicolumn{1}{|c|}{ Country } & \multicolumn{1}{c|}{ Variable } & \multicolumn{1}{c|}{ Time interval } & \multicolumn{1}{c|}{ Source of data } \\
\hline Belgium & & & \\
France & Natural logarithm & 1971Q1-2014Q4 & OECD Housing Prices \\
Germany & of real HPI index & 176 observations & database \\
Great Britain & based in 2010 & & \\
Italy & & & \\
Netherlands & & & \\
\hline
\end{tabular}

Source: author's own compilation

Frequency filters were used as a basic tool for identifying price cycles. The purpose of these statistical econometric methods is to isolate the cyclic factor of specific frequency from the original time series. The use of filters is based on the assumption that time series are composed of the basic components, which include: 
1) trend - reflects the tendency of the examined variable describing particular economic phenomenon to systematic changes over time (increase or decrease) (Gajda, 2004: 120);

2) cyclical fluctuations - variable fluctuations around the long-term trend caused primarily by the business cycle, repeated with relative regularity (Trojanek, 2008: 69);

3) seasonal fluctuations - these are regular changes in the variable value around the trend or average variable level, repeated from year to year in the same calendar periods (Dittman, 2004);

4) random fluctuations - irregular changes in the level of the variable representing the effect of unpredictable and incidental factors (e.g., war, natural disasters, or important political events) (Sobczyk, 2000: 316).

Using appropriate statistical methods it is possible to isolate the cyclical component of a time series. The first step in the research procedure is to remove seasonal and random fluctuations from the original data. The most popular methods for seasonal adjustment of a time series are X-12-ARIMA and TRAMO-SEATS (Grudkowska, Paśnicka, 2007). In this paper, the TRAMO-SEATS procedure was used for seasonal adjustment of real estate price indices.

In the next stage, in order to isolate cyclical fluctuations in real estate prices, the Christiano-Fitzgerald (CF) filter was used. This filter is a band pass filter which removes the component of high and low frequency (random fluctuations and the trend) from a time series, thereby leaving the cyclic component. There are two basic variants of the CF filter: for a stationary series I (0) and a series integrated of order 1 I (1) (Ulrichs, Błażej, Jędrych, 2014: 12). On the basis of the unit root test it was verified that all series of real estate price indices included in the study are integrated of order 1. Therefore, to isolate the cyclical factor the CF I (1) filter was applied, with the drift adjusting method taking into account the bandwidth of 12-40 quarters (the study assumed that price cycles are in the bandwidth of 3-10 years) (Adamowicz, Dudek, Pachucki, Walczyk, 2012: 12).

The isolated price cycles were subjected to the dating procedure. Turning points in the course of cycles were identified using the Harding-Pagan algorithm. In the first stage of the procedure local minima and maxima were identified using two-sided 4-quarter windows:

$$
\begin{aligned}
& \text { Peak at } t:\left(X_{t-4}, \ldots, X_{t-1}<X_{t}>X_{t+1}, \ldots, X_{t+4}\right) \text {; } \\
& \text { Trough at } t:\left(X_{t-4}, \ldots, X_{t-1}>X_{t}<X_{t+1}, \ldots, X_{t+4}\right)
\end{aligned}
$$

The second stage verified alternation of local minima and maxima occurrence. When consecutive minima (maxima) took place one after another, a quarter with 
the lowest (highest) value of cyclical component was selected as the turning point in the course of the cycle (Bracke, 2011). In addition, it was assumed that the minimum housing cycle length was 12 quarters, while the minimum length of a single cycle phase (upward or downward), was 6 quarters.

Two measures were used to assess the level of synchronisation of cycles: the correlation coefficient and concordance index. The correlation coefficient determines the strength of the interdependence of two cycles, taking into account the direction and dynamics of their course. The concordance index expresses the level of synchronisation between two cycles in the context of the compliance of their phases (compliance of turning points of cycles). Its value defines at which part of the examined time horizon the two cycles remained in the same phase (upward or downward). In the case of fully synchronised cycles, the concordance index assumes a value of 1 , while for non-synchronised cycles, it assumes a value of 0 . The concordance index is calculated based on the following formula (Akimov, Stevenson, Young, 2015: 1665-1682):

$$
C I=\frac{1}{T}\left(\sum_{t=1}^{T} S_{i t} \cdot S_{j t}+\sum_{t=1}^{T}\left(1-S_{i t}\right) \cdot\left(1-S_{j t}\right)\right),
$$

where:

$C I$ - concordance index,

$S_{i t}$ - phase of the cycle in period $t$ for the $i$ market (assumes the value of 1 in the upward phase and 0 in the downward phase),

$S_{j t}$ - phase of the cycle in period $t$ for the $j$ market (assumes the value of 1 in the upward phase and 0 in the downward phase),

$T$ - number of periods of analysis.

\subsection{Findings}

The course of cycles in the selected European economies is presented in Figure 1, and their basic characteristics are provided in Table 2. From four to six full price cycles were identified in the examined economies. The average cycle length ranged from 23 to 34 quarters. The upward phases lasted on average one quarter longer than the downward phases, however, important differences in the course of particular housing cycles were noticeable.

The analysis of the correlation matrix (Table 3) indicates that the strongest positive correlation over the whole 44-year study period was exhibited by cycles in Great Britain and France (a correlation of 0.59) as well as in Great Britain and Germany (a correlation of 0.58). Strongly, although negatively were correlated housing cycles in Italy and the Netherlands (a correlation of -0.71 ), indicating their asynchronous course in these countries. 

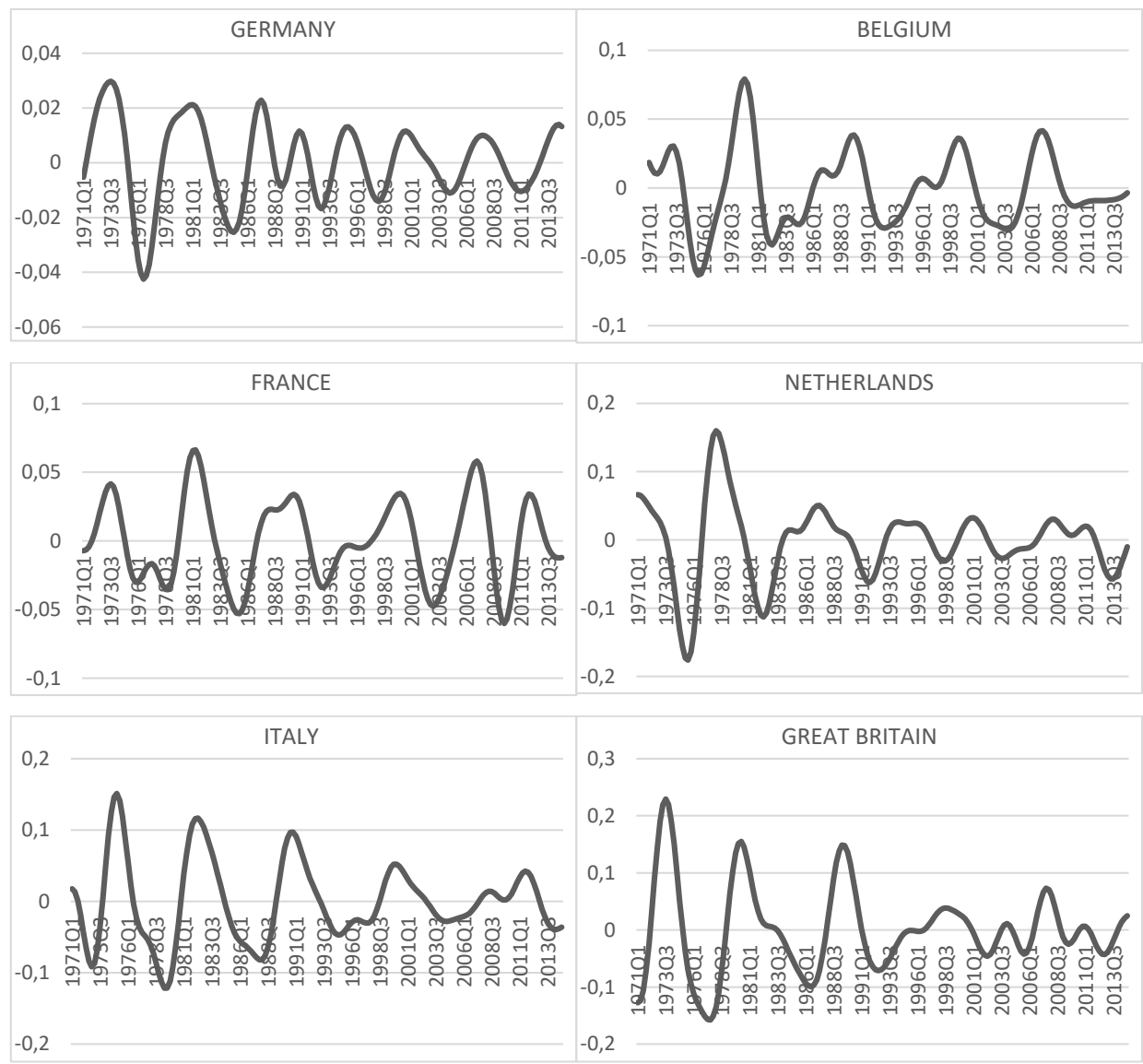

Figure 1. Price cycles in European housing markets

Source: author's own compilation

Table 2. Basic characteristics of housing cycles

\begin{tabular}{|l|c|c|c|c|c|c|c|}
\cline { 2 - 9 } \multicolumn{1}{c|}{} & BE & DE & FR & NL & IT & GB & $\begin{array}{c}\text { Average for } \\
\text { 6 economies }\end{array}$ \\
\hline The number of full cycles & 4 & 6 & 5 & 5 & 5 & 6 & 5.2 \\
\hline The average length of cycles (in quarters) & 33.8 & 22.7 & 30.6 & 30.2 & 33.2 & 26.2 & 29.4 \\
\hline $\begin{array}{l}\text { The average length of the upward phases } \\
\text { (in quarters) }\end{array}$ & 21.8 & 11.0 & 16.6 & 13.8 & 16.4 & 11.2 & 15.1 \\
\hline $\begin{array}{l}\text { The average length of the downward } \\
\text { phases (in quarters) }\end{array}$ & 12.0 & 11.7 & 14.0 & 16.4 & 16.8 & 13.8 & 14.1 \\
\hline
\end{tabular}

Source: author's own compilation 
Table 3. The correlation matrix of housing cycles

\begin{tabular}{|l|c|c|c|c|c|c|}
\cline { 2 - 7 } \multicolumn{1}{c|}{} & BE & DE & FR & NL & IT & GB \\
\hline BE & 1 & & & & & \\
\hline DE & $0.525^{*}$ & 1 & & & & \\
\hline FR & $0.488^{*}$ & $0.516^{*}$ & 1 & & & \\
\hline NL & $0.547^{*}$ & 0.137 & -0.128 & 1 & & \\
\hline IT & $-0.476^{*}$ & $-0.149^{*}$ & $0.201^{*}$ & $-0.708^{*}$ & 1 & \\
\hline GB & $0.530^{*}$ & $0.580^{*}$ & $0.591^{*}$ & -0.121 & 0.036 & 1 \\
\hline
\end{tabular}

* The correlation coefficient statistically significant at a significance level of 5\%.

Source: author's own compilation

The strongest, in terms of compliance of cycle phases, were the synchronised housing cycles of Great Britain and France (throughout $73 \%$ of the analysed period, cycles remained in the same phase), France and Belgium, as well as Great Britain and Belgium (in both cases synchronisation throughout $68 \%$ of the analysed period). The lowest level of synchronisation measured by the concordance index was recorded for housing cycles in the Netherlands and Italy (synchronisation throughout $36 \%$ of the analysed period).

Table 4. Concordance indices for housing cycles

\begin{tabular}{|l|l|l|l|l|l|l|}
\cline { 2 - 7 } \multicolumn{1}{c|}{} & BE & DE & FR & NL & IT & GB \\
\hline BE & 1 & & & & & \\
\hline DE & 0.670 & 1 & & & & \\
\hline FR & 0.682 & 0.648 & 1 & & & \\
\hline NL & 0.597 & 0.608 & 0.426 & 1 & & \\
\hline IT & 0.409 & 0.477 & 0.670 & 0.358 & 1 & \\
\hline GB & 0.682 & 0.591 & 0.727 & 0.415 & 0.534 & 1 \\
\hline
\end{tabular}

Source: author's own compilation

The next part of the study involved an attempt to assess the time stability of both measures of synchronisation of cycles. First, it was examined whether the process of enhanced economic integration of European countries, manifested by the creation of a monetary union and a common currency in 1999, had an impact on the level of synchronisation of housing cycles. For this purpose, the time interval covered by the analysis was divided into two sub-periods of research: the period 1971-1998 (the period before the introduction of the common currency) and the period 1999-2014 (the period of the common European currency) (Alvarez et al., 2010). Correlation coefficients and concordance indices were recalculated for national housing cycles in these two sub-periods, and then their arithmetic means were calculated. The results of the calculation procedure are shown in Figure 2. 
0,80

0,60

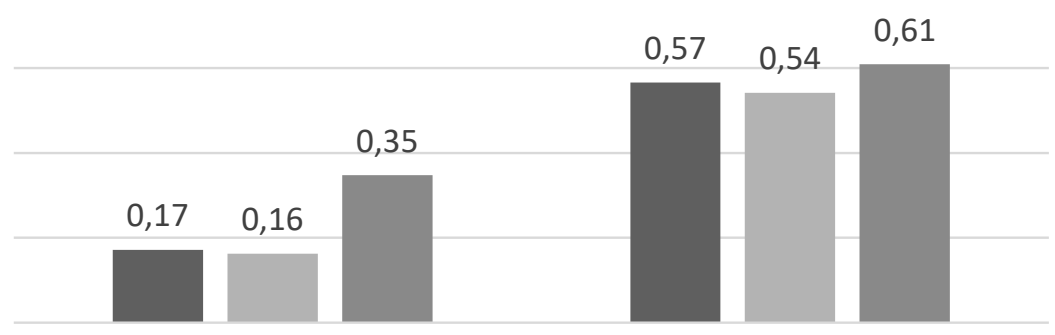

average pairwise correlation average pairwise concordance index

-1971-2014 -1971-1998 —1999-2014

Figure 2. Average values of correlation coefficients and concordance indices in the research sub-periods

Source: author's own compilation

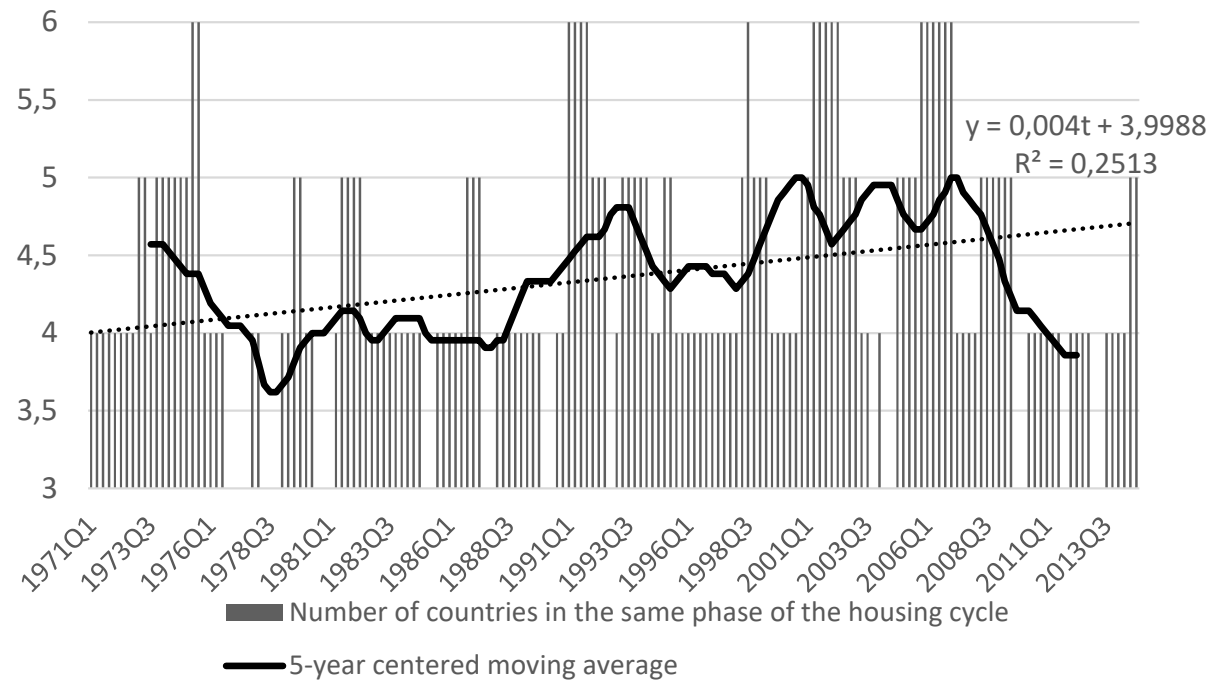

Figure 3. The number of countries remaining in the same phase of the housing cycle

Source: author's own compilation

The introduction of a common currency and monetary policy fostered the integration of financial markets of the EU countries, increased their liquidity, as well as the scale of direct and portfolio investments (Kachniewski, 2009: 194). An increase in the synchronisation of housing cycles was an indirect effect of these processes. The average value of correlation coefficients for the years 1999-2014 was over two times higher, and that of concordance indices by 7 percentage points higher compared to the average values of these measures in the period before.

The rate of change in total synchronisation of all isolated housing cycles was also analysed. For this purpose the compliance of cycle phases was verified (Fig- 
ure 3) and arithmetic means for the correlation coefficients determined on the basis of 5-year rolling windows were estimated (Figure 4) (Gayer, 2007).

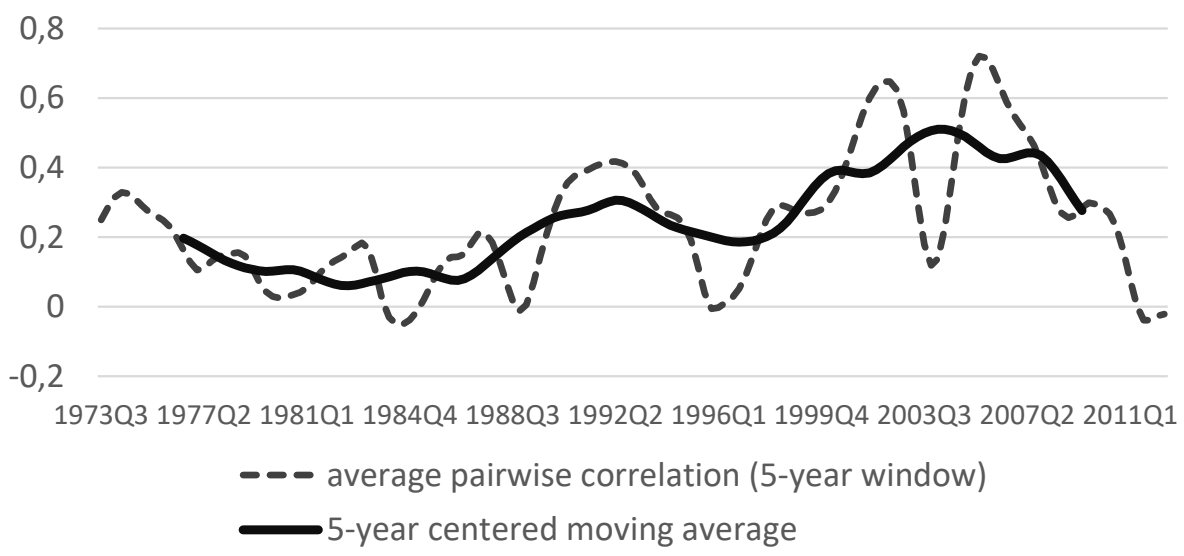

Figure 4. The average value of the correlation coefficients for the 5-year rolling windows Source: author's own compilation

Both measures confirm the general trend of increased level of synchronisation of housing cycles. In the years 1971-1998 the full compliance of phases of 6 housing cycles occurred only in 6 quarters (5.4\% of observations), while for the years 1999-2014, there were 11 such quarters (17.2\% of observations). The increase in the concurrency of cycles, however, did not proceed steadily. We can isolate periods with a lower level of their correlation (the years 1977-1988 and 1995-1997) and their stronger correlation (1989-1994 and 1998-2010).

\section{Summary}

The importance of the housing market in the national economy and the diversity of functions it performs means that fluctuations in its activity have serious economic and social implications. Historically, housing cycles were primarily of local and national nature which manifested in their individual course and dynamics. However, processes of globalisation and enhanced economic integration have given an international nature to housing cycles.

The studies conducted for the six European economies have confirmed the occurrence of synchronisation of housing cycles. Its intensity increased at the end of the 1990s, mainly due to the introduction of a common European currency and the accompanying convergence of financial markets.

Despite the increasing level of the synchronisation of housing cycles it is still significantly lower than synchronisation of other markets or of general econom- 
ic cycles, which only confirms the fact that the course of housing cycles is still heavily influenced by socio-economic, legal and institutional determinants of national nature.

\section{References}

Adamowicz E., Dudek S., Pachucki D., Walczyk K. (2012), Wahania cykliczne w Polsce i strefie euro, "Prace i Materiały Instytutu Rozwoju Gospodarczego SGH", no. 89, pp. 1-223.

Akimov A., Stevenson S., Young J. (2015), Synchronisation and commonalities in metropolitan housing market cycles, "Urban Studies", vol. 52, issue 9, pp. 1665-1682, http://dx.doi. org/10.1177/0042098014535643.

Alvarez L., Bulligan G., Cabrero A., Ferrara L., Stahl H. (2010), Housing cycles in the major euro area countries, "Documentos Ocasionales", no. 1001, Banco de Espana, http://dx.doi. org/10.2139/ssrn.1582354.

Barras R. (1994), Property and Economic Cycle: Building Cycle Revised, "Journal of Property Research", vol. 11, issue 3, pp. 183-197, http://dx.doi.org/10.1080/09599919408724116.

Bracke P. (2011), How Long Do Housing Cycles Last? A Duration Analysis for 19 OECD Countries, IMF Working Paper WP/11/231, http://dx.doi.org/10.5089/9781463921316.001.

Cagnina F. (2009), The Housing Cycle and US Economic Growth: 2002-2008, "Estudos AVANÇADOS", no. 23(66), pp. 147-168, http://dx.doi.org/10.1590/S0103-40142009000200012.

DiPasquale D., Wheaton W.C. (1994), Housing Market Dynamics and the Future of Housing Prices, "Journal of Urban Economics", vol. 35, issue 1, pp. 1-27, http://dx.doi.org/10.1006/ juec.1994.1001.

Dittmann P. (2004), Prognozowanie w przedsiębiorstwie. Metody i ich zastosowanie, Oficyna Ekonomiczna, Kraków.

ECB (2003), Structural factors in the EU housing markets, Frankfurt.

Frączek P., Mazurkiewicz A. (2013), Efekt spill-over a modernizacja krajowego sektora energii, "Przedsiębiorstwo i Region", no. 5, pp. 120-130.

Gajda J.B. (2004), Ekonometria, C.H. Beck, Warszawa.

Gayer C. (2007), A fresh look at business cycle synchronisation in the euro area, Economic Papers no. 287, European Commission.

Gołębiowski G., Szczepankowski P. (2015), Finansyzacja gospodarki krajów Europy Środkowo-Wschodniej, "Ruch Prawniczy, Ekonomiczny i Socjologiczny", Year LXXVII, no. 4, pp. 197-215.

Grudkowska S., Paśnicka E. (2007), X-12-ARIMA i TRAMO/SEATS-empiryczne porównanie metod wyrównania sezonowego w kontekście dtugości próby, "Materiały i Studia", no. 220, NBP, Warszawa, pp. 1-59.

Igan I., Kabundi A., DeSimonde F., Pinheiro M., Tamirisa N. (2010), Three cycles: housing, credit and real activity, IMF Working Paper no. 160.

Kachniewski M. (2009), Wspólny pieniądz a integracja rynków finansowych, [in:] W. Pacho (ed.), Europejska integracja monetarna od A do Z, NBP, Warszawa.

Kucharska-Stasiak E. (ed.) (2008), Cykle rynku nieruchomości a sektor bankowy, "Zeszyt Hipoteczny", no. 26, Fundacja na Rzecz Kredytu Hipotecznego, Warszawa.

Kucharska-Stasiak E. (2016), Ekonomiczny wymiar nieruchomości, Wydawnictwo Naukowe PWN, Warszawa.

Lis P. (2015), Cykle mieszkaniowe. Rola rynku i państwa, Wydawnictwo Uniwersytetu Ekonomicznego w Poznaniu, Poznań.

Micał M. (2008), Proces globalizacji we współczesnym świecie, “ZNZE WSIiZ”, no. 3(8), pp. 148-171. 
Nykiel L. (2008), Sytuacja mieszkaniowa i rozwój rynku mieszkaniowego, “Zeszyt Hipoteczny”, no. 28, Fundacja na Rzecz Kredytu Hipotecznego, Warszawa.

Pomagajko K., Voigtlander M. (2012), Co-movement of house price cycles - a factor analysis, "International Journal of Housing Markets and Analysis", vol. 5, no. 4, pp. 414-426.

Sobczyk M. (2000), Statystyka. Podstawy teoretyczne, przykłady-zadania, Wydawnictwo UMCS, Lublin.

Sporek T. (2015), Procesy globalizacji we wspótczesnej gospodarce światowej, "Ekonomia XXI Wieku", no. 1(5), pp. 47-67, http://dx.doi.org/10.15611/e21.2015.1.03.

Trojanek R. (2008), Wahania cen na rynku mieszkaniowym, Wydawnictwo Akademii Ekonomicznej w Poznaniu, Poznań.

Ulrichs M., Błażej M., Jędrych J. (2014), Równoległy oraz wyprzedzajacy zagregowany wskaźnik koniunktury, zegar koniunktury. Identyfikacja mechanizmów i przebiegu cyklu koniunkturalnego dla Polski. Metodologia, GUS, Warszawa.

Vansteenkiste I., Hiebert P. (2009), Do house price developments spill over across Euro area countries? Evidence from a global VAR, ECB, Working Paper no. 1026.

\section{Synchronizacja cykli cenowych na europejskich rynkach mieszkaniowych}

Streszczenie: Rynek mieszkaniowy pełni istotną rolę w każdej gospodarce. Jego znaczenie determinowane jest nie tylko rozmiarami sektora mieszkaniowego, lecz także szeregiem funkcji społeczno-ekonomicznych realizowanych przez nieruchomości mieszkaniowe. Tak jak każdy inny rynek czy cała gospodarka, rynek mieszkaniowy rozwija się cyklicznie. Historycznie cykle mieszkaniowe kształtowane były przede wszystkim przez czynniki krajowe. Jednak postępująca integracja gospodarek w ramach Unii Europejskiej sprzyja procesowi sukcesywnej synchronizacji krajowych cykli mieszkaniowych. Celem artykułu była identyfikacja cykli mieszkaniowych w wybranych gospodarkach europejskich, a także ocena stopnia ich synchronizacji. Badaniem objęte zostały rynki mieszkaniowe w Belgii, Francji, Holandii, Niemczech, Wielkiej Brytanii oraz Włoszech w latach 1971-2014. Do wyodrębnienia cykli cenowych wykorzystano filtr Christiano-Fitzgeralda, natomiast w ocenie ich synchronizacji zastosowano współczynniki korelacji oraz indeks konkordancji. Uzyskane wyniki potwierdziły występowanie zjawiska synchronizacji cykli mieszkaniowych. Jego intensywność nasiliła się z końcem lat dziewięćdziesiątych, a jedną z jego głównych przyczyn było wprowadzenie wspólnej waluty europejskiej i towarzysząca mu konwergencja rynków finansowych.

Słowa kluczowe: europejskie rynki mieszkaniowe, cykle mieszkaniowe, synchronizacja cykli mieszkaniowych

JEL: R31, E32

\begin{tabular}{|l|l|}
\hline \multirow{2}{*}{ OPEN ACCESS } & $\begin{array}{l}\text { C by the author, licensee Łódź University - Łódź University Press, Łódź, Poland. } \\
\text { This article is an open access article distributed under the terms and conditions } \\
\text { of the Creative Commons Attribution license CC-BY } \\
\text { (http: //creativecommons.org/licenses/by/3.0/) }\end{array}$ \\
\cline { 2 - 2 } & Received: 2016-08-14; verified: 2017-07-31. Accepted: 2018-01-02 \\
\hline
\end{tabular}

